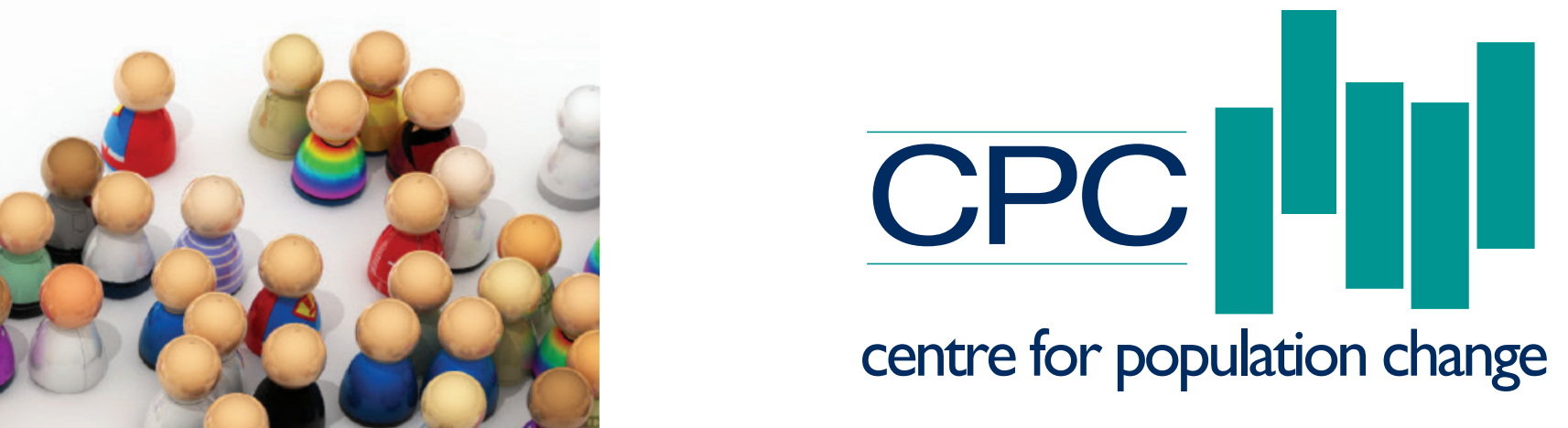

\title{
Women as main earners in Europe
}

$\mathrm{E} \cdot \mathrm{S} \cdot \mathrm{R} \cdot \mathrm{C}$ (1) ECONOMIC \& S O C I A L RESEARCH C OUN C I L
Agnese Vitali Daria Mendola 


\section{ABSTRACT}

This paper conducts a cross-sectional empirical research aimed at documenting that couples with women as main earners represent a non-negligible share of the European populations today. We identify the socio-demographic characteristics of couples with women as main earners in comparison to couples with men as main earners and couples with equal-earners. We undertake a comparative and cross-temporal approach using micro-level survey data for 18 European countries from the European Social Survey and two years, 2004 and 2010, covering the period before and during the economic crisis.

\section{KEYWORDS}

European Social Survey; Family Change; Women as main earners; Gender Roles.

\section{EDITORIAL NOTE}

Agnese Vitali is a Lecturer in Social Statistics and Demography at the University of Southampton and member of the ESRC Centre for Population Change.

Daria Mendola is a Tenured Assistant Professor in Social Statistics at the University of Palermo, Department of Economics, Business and Statistics.

Corresponding author: Agnese Vitali, A.Vitali@soton.ac.uk. 


\section{ACKNOWLEDGEMENTS}

The authors would like to thank participants to the 2014 Population Association of America Annual Meeting, to the 2014 European Population Conference and members of the Family Lunch group at the University of Southampton for useful comments and discussions.

(C) Agnese Vitali and Daria Mendola all rights reserved. Short sections of text, not to exceed two paragraphs, may be quoted without explicit permission provided that full credit, including $\odot$ notice, is given to the source.

The Working Paper Series is edited by Teresa McGowan.

\section{ESRC Centre for Population Change}

The ESRC Centre for Population Change (CPC) is a joint initiative between the Universities of Southampton, St Andrews, Edinburgh, Stirling, Strathclyde, in partnership with the Office for National Statistics (ONS) and the National Records of Scotland (NRS). The Centre is funded by the Economic and Social Research Council (ESRC) grant numbers RES-625-28-0001 and ES/K007394/1.

This working paper series publishes independent research, not always funded through the Centre. The views and opinions expressed by authors do not necessarily reflect those of the CPC, ESRC, ONS or NRS.

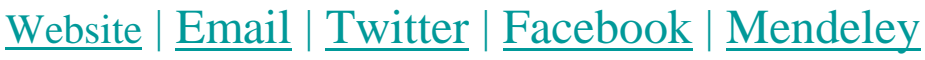




\section{WOMEN AS MAIN EARNERS IN EUROPE}

\section{TABLE OF CONTENTS}

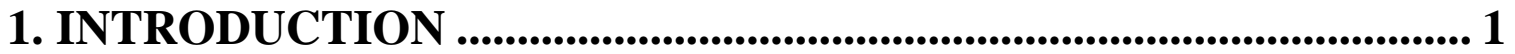

2. PREVIOUS FINDINGS ON THE CORRELATES OF WOMEN AS MAIN EARNERS................................................... 4

2.1. INDIVIDUAL CHARACTERISTICS................................................................ 4

2.1.1. GENDER OF RESPONDENT ……………...................................... 4

2.1.2. AGE AND COHORT ……………………………............................ 5

2.1.3. FEMALE EDUCATIONAL EXPANSION .............................................. 5

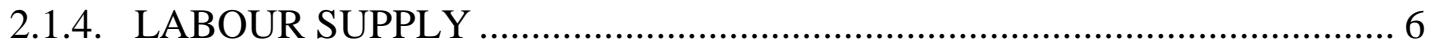

2.2. HOUSEHOLD-LEVEL CHARACTERISTICS................................................. 6

2.2.1. CHILDREN IN THE HOUSEHOLD ...................................................... 6

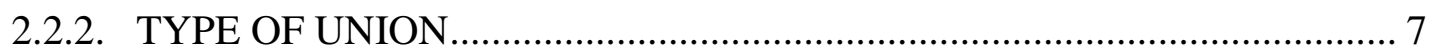

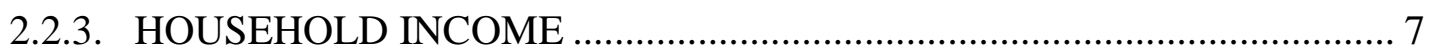

2.2.4. CONTEXT: TIME AND PLACE .............................................................. 7

3. DATA AND METHODS ...................................................................... 8

4. DESCRIPTIVE RESULTS ............................................................. 12

5. RESULTS FROM MULTINOMIAL LOGISTIC

REGRESSIONS ....................................................................... 18

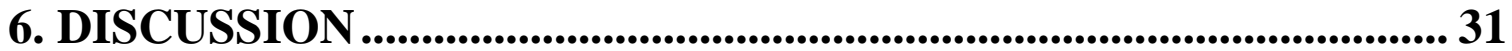

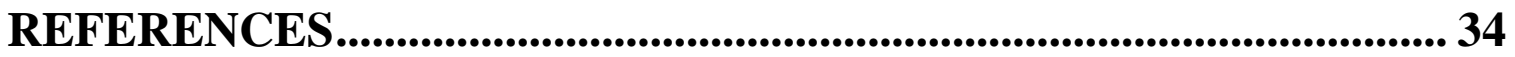




\section{INTRODUCTION}

Traditionally, men partnered with women who had attained the same or a lower educational level than themselves and were almost always the sole or main wage earner. Historically women from low social classes partook in paid employment while their higher classed counterparts did not. However their contribution to the household income was marginal in comparison to that of the male breadwinner (Esping-Andersen 2009).

Since the mid- $20^{\text {th }}$ century, the economic change brought about by World War II favoured male employment and increased male wages, thereby establishing the malebreadwinner model as the predominant family model in Western societies. In other words, the women's role as income providers was seen as an adaptive strategy to supplement the household income when the economic circumstances required it. The specialization of gender roles with men working and women staying at home was justified by the New Household Economics perspective as the arrangement best able to maximize the couple's utility, and was advocated as the only possible arrangement for marrying and staying married (Parsons 1949; Becker 1981). Hence, many societal aspects were implicitly built on the notion that the male-breadwinner model was in place and welfare systems were structured around the gendered division of work and care tasks (Crompton 1999; Lewis 2001).

However, the male-breadwinner model has been challenged as women entered higher education and employment, and started to earn income, stimulating the rise of the dual-earner family (Blossfeld et al. 2001; Oppenheimer 1994). In addition, changes in individuals' ideals and values has led to a decline in the centrality of the family and new family arrangements have emerged, such as solo-living, lone motherhood, divorce and non-marital cohabitation (Van de Kaa 1987), that have further eroded the normative role of men as breadwinners (Lewis 2001).

As of 2013, employment rate for women in prime earning age (25-54 years old) in the European Union (EU-27) was equal to 71.1\%, against 82.6\% for men, indicating that, although men are still more likely to be employed than women, the gender gap in the 
labour market has reduced considerably over time (own analysis on Labour Force Survey data, Eurostat). Over time, while the economic position of men in the labour market worsened due to lower earning potential and higher unemployment rates, average women's earnings have continued to rise as more women entered managerial and professional occupations and the economic role of women has become central and not just supplementary (Oppenheimer 1994; Bernhardt et al. 1995). Studies show that the gender gap in earnings persists in that men are more likely to earn higher incomes than women, regardless of the level of education achieved. Nonetheless the gap is shrinking (OECD 2013; Vincent-Lancrin 2008). Today, the younger generations of women are, on average, more educated than men are. In 2005 there were 1.3 female graduates for each male graduate on average across OECD countries (Vincent-Lancrin 2008). In 2011, the proportion of students who entered tertiary education and graduated with at least a first degree was $10 \%$ higher for women (71.9\%) than it was for men (61.8\%) (OECD 2013).

It is therefore not surprising that in developed countries today, in an increasing number of heterosexual couples, women earn more than their male partners. The share of couples where the woman is the sole earner, which includes stay-at-home fathers and lone mothers, and that can be referred to as "female breadwinner" families, is also on the rise, but still represents a small proportion of households (Harkness 2010). Today, malebreadwinner couples where the woman does not work in the labour market and the man is the sole provider represent less than $40 \%$ of the households in the developed world, ranging from below 15\% in France, Denmark, Norway, Sweden and the US, to 31\% in Italy and 38\% in Spain (Harkness 2010). Couples where the woman's share of the total couple's earnings exceeds $50 \%$ (i.e. the wife earns more than the husband) represent about one in four married couples with (Wang et al. 2013) or without (Winkler et al. 2005) children in the US, one in five married or cohabiting couples in France (Bloemen et al. 2013) and one in four married and cohabiting couples in Australia (Wooden et al. 2014). The numbers, however, differ substantially when different measures are used. For example, couples where the woman's share of the total couple's earnings exceeds $60 \%$ represent about one in five married couples in the US (Winkler et al. 2005) and only 4\% in France (Bloemen et al. 2013). 
Who are the couples with women as main earners? How are they different from couples with different earning arrangements? Do the correlates of the different earning arrangements vary across countries? These are the questions that our study seeks to answer.

Most of the existing studies on women who out-earn their partners describe the earnings of families in the U.S. and Australia and were conducted on data collected two decades ago or more (Atkinson et al. 1984; Winkler et al. 2005), and hence disregard the social change concerning women and their role that occurred during the most recent decades. Also, during the economic crisis, many developed countries have witnessed declining real earnings and increased unemployment rates in particular for men, because men are mainly employed in the economic sectors which were the most hardly hit by the crisis (construction, manufacturing and financial) (Cho et al. 2012; Harkness 2013). ${ }^{1}$ Using household-level income data, Bettio et al. (2012) find that between 2007 and 2009, across European countries, the proportion of dual-earner couples declined by 5.1 percentage points and female breadwinner couples increased by 4.7 percentage points over the same years, on average. Hence, an increasing number of households have become dependent upon women’s labour income.

Research on the situation in Europe is lacking on this topic. The comparison of different institutional and cultural settings within Europe can help us to shed light on the emergence of women as main earners and in particular on the role of welfare systems and labour market regulations (Bianchi et al. 1999; Rubery 2010).

Using up-to-date micro data for 18 European countries from the European Social Survey, this paper contributes to the existing literature in three ways. First, it documents the prevalence of couples with women as main earners in Europe. Second, following the analytical framework used by Raley et al. (2006), it studies the characteristics, or correlates, of couples with women as main earners (WME hereafter) in comparison to couples with different earning arrangements, i.e. men as main earners (MME) and equal

\footnotetext{
${ }^{1}$ The employment rate for men aged 25 to 59 years in the EU-27 declined from $86.8 \%$ in 2007 to $82.6 \%$ in 2013, while it remained stable at 71\% for women (own analysis on Labour Force Survey data, Eurostat).
} 
earners (EE). Third, it compares two points in time covering the period before and after 2008, i.e. the year the economic crisis started in Europe. This means that we are able to investigate if the relevance of the economic role for women within the family has become more widespread during the economic crisis or if it was detectable already in 2004, i.e. well before the crisis had begun.

\section{PREVIOUS FINDINGS ON THE CORRELATES OF WOMEN AS MAIN EARNERS}

Research explicitly looking at women who out-earn their partners has been scarce, in particular for Europe. The majority of existing studies on the characteristics of women and men in different earning regimes, including breadwinner women, focused on the US with few exceptions, e.g. Bianchi et al. (1999) who compared the US with Australia, Canada and six European countries; Drago et al. (2005) and Wooden et al. (2014) on Australia, and Bloemen et al. (2013) on France. Most of the existing knowledge is based on data that date back to the 80s (Atkinson et al. 1984; Bianchi et al. 1999), 90s (Winkler et al. 2005), or early 2000s (Raley et al. 2006; Drago et al. 2005; Bloemen et al. 2013). In the remainder of this section we review the characteristics that were found to be associated with the distribution of couples across different earning regimes, in particular focusing on couples in the WME, EE and MME arrangements.

\subsection{INDIVIDUAL CHARACTERISTICS}

\subsubsection{GENDER OF RESPONDENT}

Studies have documented the existence of a discrepancy in the personal income reported by the respondent and his or her spouse. Men typically report higher household income and wealth compared to women (Zagorsky 2003). Qualitative findings in Singh et al. (2010) show that husbands have a tendency to over-reporting income in general, whether their own or their spouses'. Women, on the other hand, tend to underreport. Hence, the measures of the couple's relative earnings reported by one of the partners may be biased depending on the respondent's gender. This bias may be augmented in couples where the man is not the main earner because both men and women may try to minimize the cost of being perceived as “deviant” by hiding their actual earning arrangement (Atkinson et al. 1984). Deutsch et al. (2003), for example, find that, on average, men who report to 
contribute about the same share of the household income as their partners (i.e. to be equal earners), earn significantly less than their partners.

\subsubsection{AGE AND COHORT}

We may expect that young women are more likely to out-earn their partners compared to older women because they have higher labour force participation and higher educational attainment than women of older generations. For example, Bianchi et al. (1999) found that older women were more likely to show a higher earnings dependency on their spouses in seven out the nine countries in their study. Other empirical studies instead found no or weak association between age/cohort and relative earnings (Raley et al. 2006; Bloemen et al. 2013). Age difference between the partners is found to be important. Historically, the vast majority of marital heterogamy by age was made of men partnering with younger women. The explanation was based on the "gendered double standard of aging”, i.e. on asymmetric career opportunities, according to which young women choose to partner with older men who have a higher earning potential than they have, as well as on attractiveness, according to which wealthy men are more willing to partner with younger women (England et al. 2009; Hakim 2010). As more women are found to have a higher earning potential than their partner today, some have hypothesised that a reversal of the "gendered double standard of aging" holds, with older successful women willing to partner with younger men and vice versa. For example, Coles et al. (2011) document the emergence of what they call "toyboy marriages" in the UK and US in the recent years i.e. marriages in which the woman is older than the man. They found that women who earn more, achieved higher education and had a more prestigious occupation than their partners' were more likely to marry a younger man. A similar result is found also in Bloemen et al. (2013) for France.

\subsubsection{FEMALE EDUCATIONAL EXPANSION}

One of the consequences of the unprecedented female educational expansion is the recently documented departure from the traditional assortative mating that characterized the marriage market in the past, and a parallel increase in the number of couples where women are more educated than their partners (Schwartz and Mare, 2005). But the “reversal of gender inequality in education” (Van Bavel 2012) may also bring an increase in the economic role of women as main income providers for their families. In fact, 
women who are more educated than their partners are found to be less economically dependent on their partners (Bianchi et al. 1999) and more likely to provide the largest share of the household income (Raley et al. 2006, Bloeman et al. 2013). But, having achieved a bachelor degree or more per se does not seem to explain why women are main earners versus equal earners (Raley et al 2006; Wooden et al. 2014).

\subsubsection{LABOUR SUPPLY}

Previous studies have found that women who out-earn their partners are likely to have traditionally male jobs and husbands with flexible jobs (Atkinson et al. 1984). Drago et al. (2005) identify a typology of couples on the basis of two underlying reasons that drive women to become the main earners. On the one hand, gender equality among the partners may favour the WME arrangement, in particular when the woman has a higher earning potential than the man, and as such, this type of earning arrangement is more likely to persist over time. On the other hand, women as main earners may emerge as a response to a failure of men in the labour market. In this case, the earning arrangement may be permanent, as in the case of long-term unemployment spells and persistent low wage for the man, or temporary. Crompton et al. (1995) found that men experienced an unemployment spell in about 30\% of couples with WME in Canada in the early 1990s. Women who work full-time and men who work part time or are unemployed are more likely to be found in the WME arrangement (Bianchi et al 1999; Raley et al. 2006; Drago et al. 2005). In particular, male unemployment is particularly relevant today because the economic crisis has mainly affected the male-dominated sectors.

\subsection{HOUSEHOLD-LEVEL CHARACTERISTICS}

\subsubsection{CHILDREN IN THE HOUSEHOLD}

The presence of children in the household, especially of young children, is found to negatively correlate with the probability that the woman out-earn her partner because mothers are more likely to be out of the labour market for childcare or are more likely to reduce the total number of hours in paid employment (Bianchi et al. 1999; Raley et al. 2006; Bloemen et al. 2013). 


\subsubsection{TYPE OF UNION}

The majority of existing studies on women as main earners focuses on married couples. However, excluding cohabiting couples may cause an underestimation of the prevalence of women as main earners as cohabiting unions represent more than half of all unions in many European countries, in particular the Nordic countries. Previous studies have shown that income, especially men's income, is positively related to marriage, while it is less important for entry into cohabitation (Kalmijn 2011). Bloemen et al. (2013) documented for France that women as sole earners are more widespread among cohabiting than married couples, while cohabitation is negatively associated with WME as well as with the traditional male-breadwinner model. This result suggests that marriage is still associated with traditional earning arrangements where the man is the main income provider.

\subsubsection{HOUSEHOLD INCOME}

Bianchi et al. (1999) found non-labour income to be negatively associated with wives' earning dependency on their spouses in Nordic and Liberal countries, but not in Conservative countries. North American couples with women earning the majority of the household income are more widespread among low-income households (Smith 2009). Crompton et al. (1995) found that average household income in couples with the woman as the sole earner was $12 \%$ lower than that in couples with the men as the sole earner. Also, in the case of women as sole earners, public and private transfers contributed to almost half of the total household income versus one fifth when the man is the sole earner. Descriptive statistics for Australia in Drago et al. (2005) suggest that household wealth is considerably high if the WME arrangement is persistent, while it is considerably low if the WME arrangement is only temporary, i.e. mainly driven by failures of men in the labour market.

\subsubsection{CONTEXT: TIME AND PLACE}

Most of the findings that we have reviewed so far draw on data on one country or a small set of countries collected during the 80s and 90s. These findings need not necessarily apply to European countries in the early 2010s, considering the unprecedented changes in 
female education and empowerment that have undergone in the most recent decades. Indeed time and place are equally important elements that need to be taken into account when studying relative earnings and women economic power. Raley et al. (2006) show that the correlates of the earning arrangements of couples changed over time in the US. Some predictors which were able to explain the existence of couples with women as main earners in the 1970s were no longer significant in 2001. Bianchi et al. (1999) reflect on the importance of context for correctly understanding the determinants of earning arrangements across different countries. Classifying countries into the three welfare regimes originally proposed by the Esping-Andersen (1990), Bianchi et al (1999) found that, in the 1980s, some correlates of female earning dependency showed within-regime homogeneity and differences across regimes, while other correlates, e.g. children in the household, were common to all countries, irrespectively of the welfare system. They concluded that gender and stratification inside the family needed to be taken into account when grouping countries, but also that no welfare system had managed, at least then, to eliminate gender inequality. Time also matters in our context. The prevalence of women as sole or main earners has been found to increase during economic recessions. During the Canadian recession of 1990-92, couples with women as main earners reached 25\%, increasing by $6 \%$ after a decade of stability at around $19 \%$ (Crompton et al. 1995). Also, women's contribution to the household income registered a statistically significant increase among American families between 2007 and 2008 (Smith 2009).

\section{DATA AND METHODS}

This paper uses data from the European Social Survey (ESS), a repeated cross-sectional survey aimed at measuring values and behaviours of Europeans. The ESS proves to be useful since two of its rounds contain rotating modules devoted to the study of family, work and wellbeing as well as self-reported socio-demographic information on partners. We focus on couples in 18 countries and two time periods, 2004 and 2010. Particularly relevant for this paper is a survey question which allows identification of the main earner on the basis of the most common definition, i.e. the person who earns the majority of the household income. The question reads as follows: "Around how large a proportion of the household income do you provide yourself?” and possible answers are in a scale from 1 “None” to 7 “All”. Using this question we identify three earning models i.e. couples of married or cohabiting partners where the woman is the main earner (WME), i.e. she 
provides over half, a very large proportion or all household income or he provides none, very small or under half; the man is the main earner (MME); both partners are equal earners (EE), i.e. they provide about the same share of the total household income. Since we are relying on a subjective and qualitative measure for identifying the main earner within a couple, we don't' need to superimpose a threshold which is intrinsically arbitrary in studies of household income (Winkler et al. 2005; Bloemen et al. 2013; Kanji 2010). ${ }^{2}$

ESS does not provide information on both partners, which means that for most of the variables we have only the respondent's perspective. In order to fully exploit our data, we include both women and men in our analyses. For the sake of clarity in the interpretation of the results, we reversed the available information in terms of the woman's perspective. The final sample is constituted of about 13,000 women and men in prime earning age (25-54 years old), who are currently co-residing with a heterosexual spouse or partner. Given that the paper focuses on women as main earners, we restrict our sample to working women, while we consider both employed and unemployed men. We excluded cases where the respondent or the partner is disabled, in education, in military service, or retired. Moreover, since we use the respondent's self-reported contribution to household income, we restrict our attention to nuclear families, i.e. households constituted by the respondent, the partner and, if present, their children. Cases where the youngest child is aged 25 years or more are excluded from our sample because adult children may more likely contribute to the household income. ${ }^{3}$

Instead of estimating separate models for each country and with the aim of having results which are based on an adequate sample size, we group countries on the basis of social and public policies. We use a classification that takes into account the promotion of female labour force participation, gender equality, family-friendly policies and attitudes/cultures supporting women's empowerment and work-family reconciliation

\footnotetext{
${ }^{2}$ Our analyses (not shown) find that the distribution of the couples' earning that we obtain using the 2010/2011 ESS survey data roughly matches the percentages obtained using relative earnings of both partners based on household-level data from the 2009 European Survey on Income and Living Conditions (EU-SILC) as presented in Bettio et al. (2012).

${ }^{3}$ We do not have information on the occupational status of the children and therefore we cannot infer whether they actually contribute to the household income or not. The threshold for age 25 was chosen because in many countries it coincides with completing higher education and leaving the parental home.
} 
(Lewis 2001; Daly and Rake 2003; Matysiak 2011). These policies are relevant to our aims because they may promote or interfere with the existence and diffusion of women as main earners. We group countries into the following six clusters:

Anglo-Saxon countries (UK and Ireland). In these countries the reconciliation of work and family life is not well-developed and couples receive limited support both in terms of leave provisions and, in general, public care arrangements. Welfare is mainly linked to the prevention of poverty.

Central and Eastern European countries (Czech Republic, Hungary, Poland, Slovakia, and Slovenia). Although characterized by a generous welfare system during the socialist period that aimed at favouring female labour force participation and reconciliation of family and work, the conditions induced by the political transformation were detrimental for the participation of women in the labour market. Today, this group of countries is characterized by a high diversity of family policies which makes within-group comparisons difficult to generalize.

Continental countries (Belgium, France, and Netherlands). Welfare is organized around employment. Belgium and France provide extensive childcare facilities and show high rates of female labour force participation. In the Netherlands, part-time work for women is a means to reconcile family and work, but at the same time reduces access to economic resources.

German-speaking countries (Germany and Switzerland). The support granted to working mothers is low. The family is viewed as the main provider of care and welfare tends to support the traditional male-breadwinner model.

Nordic countries (Denmark, Finland, Norway, and Sweden). These countries are characterized by a universalistic and interventionist welfare state and high levels of gender equality both in public and private sphere. They have the best performance in terms of reconciliation of work and family and they offer policies aimed at supporting 
gender equality, public care services, and re-employment of mothers after the birth of a child. Female labour force participation is universal.

Southern European countries (Spain and Greece). The public care system is minimal and financial assistance for families nearly non-existing. Care work is almost entirely confined within the family and the role of women in the society is still perceived to be traditional. Female labour force participation is low.

As with all classifications of countries, ours is not without limitations. However, for the purposes of this paper, this classification is a better solution than other popular classifications of countries into welfare regimes (see e.g. Esping-Andersen 1990; Ferrera 1996) which do not explicitly focus on gender issues and on the role of women.

Among the 18 countries considered in this study, the Southern European countries and Ireland were the most hardly affected by the 2008 economic crisis, especially in terms of increased male unemployment. German-speaking countries were the least affected. Germany, in particular, is the only country that registered a decline in economic vulnerability (Aassve et al. 2013).

We estimate multinomial logistic regressions to identify the main sociodemographic characteristics associated with each of the three family models. We arranged explanatory variables in four main sets (reference categories are in italics):

1) Individual characteristics (self-reported or reported by the partner, depending on gender of respondent). For the woman we consider her birth cohort (1950-1959; 19601969; 1970-1986), educational attainment (low, medium, high), and whether she works part-time or full-time. We control for gender of respondent (woman) and whether the man is unemployed or works part-time vs. full-time. 
2) Characteristics of the woman in relation to men's characteristics. We consider whether the woman is younger, of the same age or older than her partner ${ }^{4}$ and whether she is less, equally or more educated.

3) Household-specific characteristics. We consider the presence of children in the household (no children, one, two or more children), whether a child under 3 years of age is present in the household and whether the partners are in a marital or in a non-marital union. We also include a measure of the household income distinguishing households whose income lies in the (poorest) first quintile of the country-specific income distribution, between the second and the fourth quintile or in the (richest) fifth quintile.

4) Country and year. We use a dummy for the year taking value 1 for 2010 and 0 for 2004, which we interpret as a comprehensive measure of the presence/absence of the economic crisis. We include country dummies in the regression model for each country group, also an interaction with the year dummy (the reference country is the one with the lowest proportion of women as main earners within their country group as assessed in 2004).

\section{DESCRIPTIVE RESULTS}

We start by describing the distribution of couples with respect to the relative contribution to the household income in the ESS sample, considering all couples, independently of whether the woman is employed or not (Fig. 1).

There are interesting differences across countries and country groups. In 13 out of 18 countries, the modal category in the ESS sample is represented by couples where women contribute under a half of the household income in 2010. The exceptions are Greece, where the majority of couples are such that the woman provides no income, and Spain, France and Slovenia, where the majority of couples is such that women provide about half, i.e. they are equal earners. If we compare the modal category of 2010 with

\footnotetext{
${ }^{4}$ Women are older (younger) than their partner if they were born at least two years before (after) their partners, and they are of the same age if they were born the same year, one year before or after their partners.
} 
that observed in 2004, Slovenia shows no change, France registered a shift from under a half to about half and Spain registered a shift from under a half to about half. In Sweden, the distribution appears to be bimodal with exactly $40 \%$ of couples in which women contribute half and $40 \%$ contributing under a half. The distribution of couples is concentrated in the lower categories in all 18 countries, i.e. in the majority of couples women provide about half or less of the household income. Slovenia presents the most symmetric distribution in the sample, with the percentage of couples with women who provide more than half equalling the percentage of those who provide less than half. 
Southern Europe

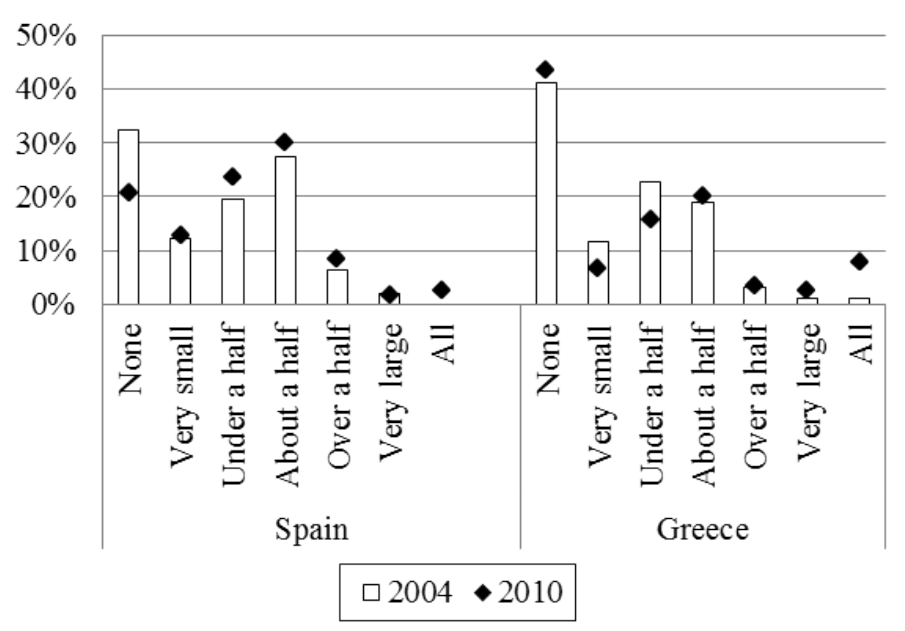

Anglo-Saxon Countries

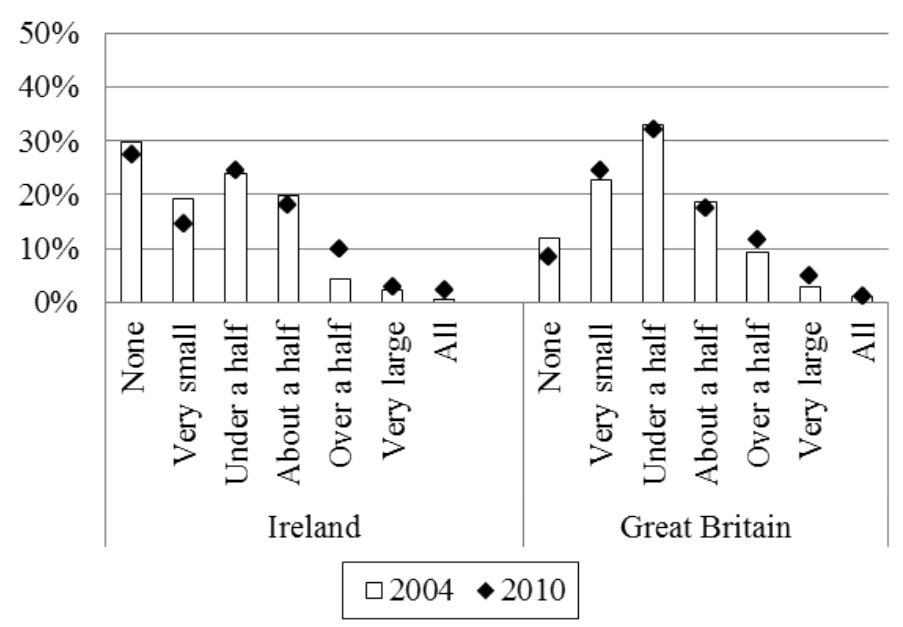

\section{German-speaking Countries}

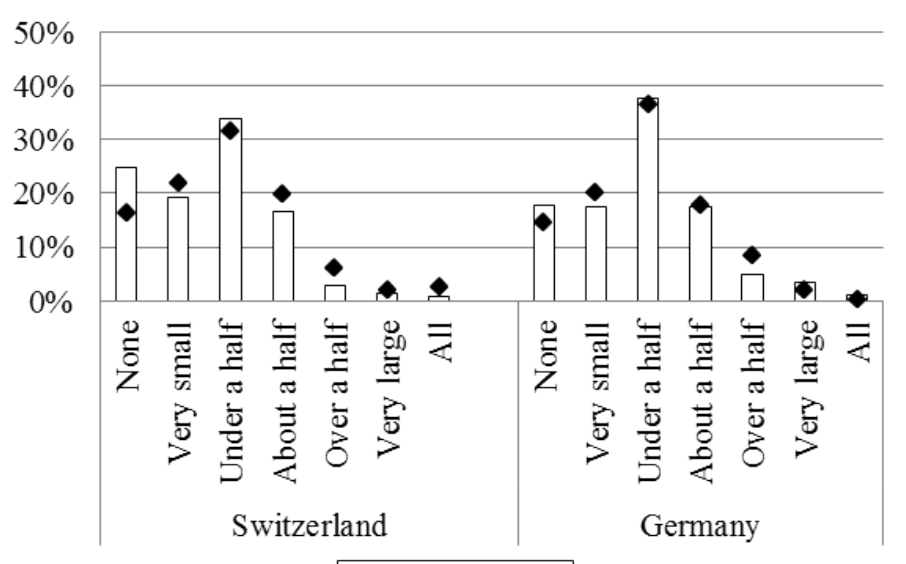

Continental Countries

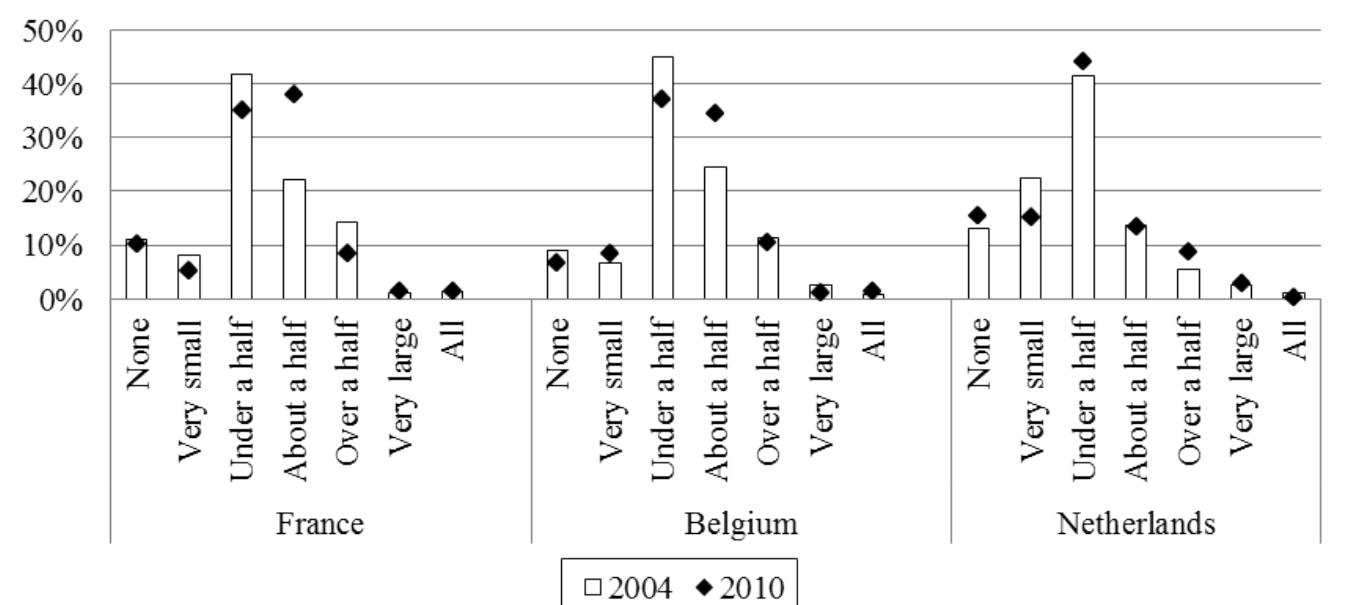

Figure 1: Percentage of couples by woman's contribution to the household income, 2004 and 2010 


\section{Central and Eastern European Countries}

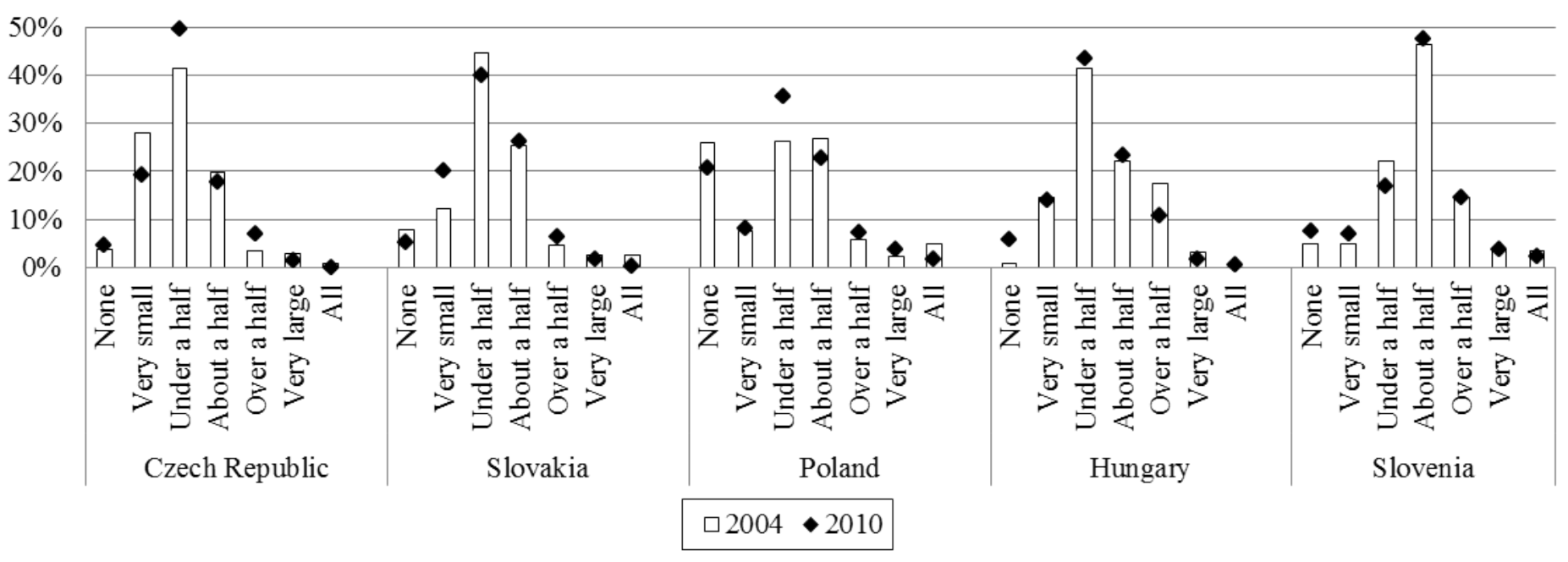

\section{Nordic Countries}

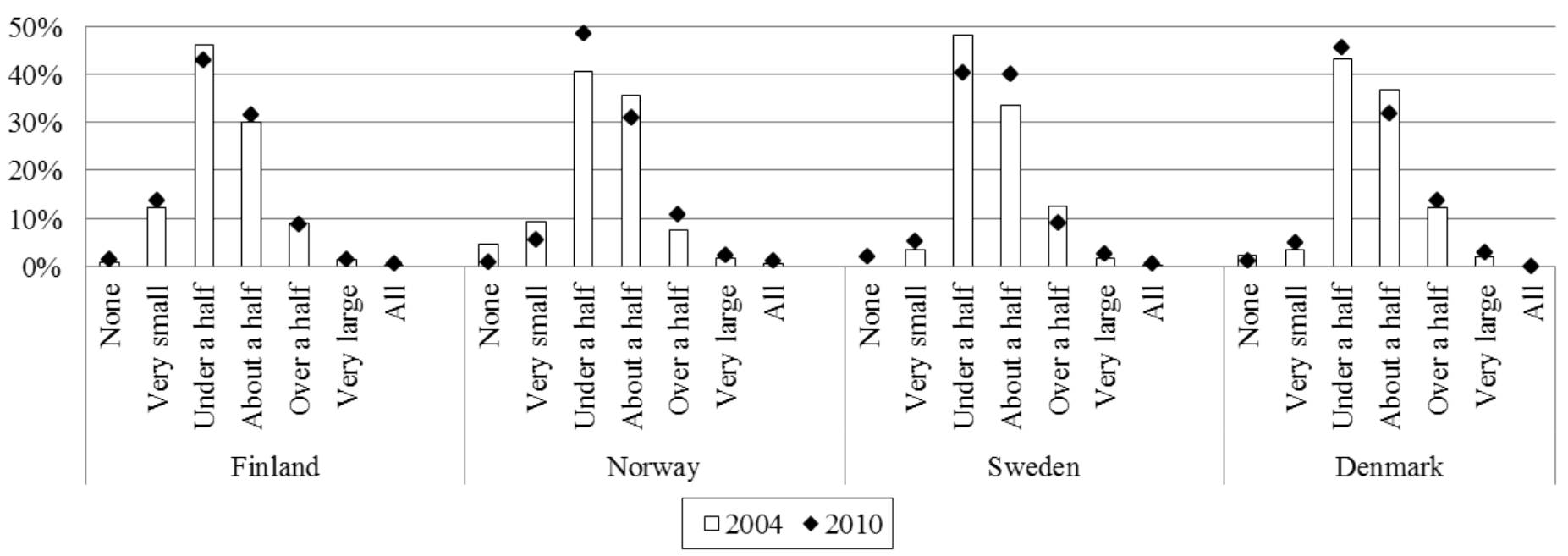

Figure 1 (Continued): Percentage of couples by woman's contribution to the household income, 2004 and 2010 
The percentage of couples with women contributing no household income mirrors the different female labour force participation rates across countries. This percentage is high among Southern European countries (44\% in Greece and 21\% Spain in 2010) and Ireland (27\%), intermediate in German-speaking countries (15\% in Germany and 16\% in Switzerland), around or below 10\% in UK, Continental and Central-Eastern European countries (with the exception of the Netherlands and Poland, $15 \%$ and 21\%), while it is very low (below 2\%) in all the Nordic countries.

The percentage of couples where women contribute a very small portion of their household income is highest in Anglo-Saxon (around 25\%) and German-speaking (around 20\%) countries. Central-Eastern European countries that show a low percentage of couples where women contribute no income, are, on the other hand, characterized by a high percentage contributing a very small portion of household income (about 20\% in Czech Republic and Slovakia, 14\% in Hungary). Among Continental and Nordic countries, the same proportion accounts to about $10 \%$ or less with the exception of Netherlands and Finland where it is slightly higher (about 15\%). Couples with women providing all of the household income represent a negligible percentage of all couples for all countries in our sample. However, we notice an increase in this proportion between 2004 and 2010 in Southern European countries, especially in Greece (from 1\% to 8\%). In the Nordic countries, women are most likely to contribute under a half and about half to the household income. The category "over a half" is slightly more represented than "very small”, except for Finland where the two categories are about the same.

Since the absence of women who out-earn their partner is systematic when she does not work, from now on we will consider only couples in which the woman has a paid work. Table 1 shows the percentage distribution of couples with a working woman into three earning arrangements in 2004 and 2010; women main earners (WME), equal earners (EE) and men main earners (MME), these will be our variables of interest in the next sections. In 2010 the majority of working women in Europe are out-earned by their partners (58\%), suggesting that men still hold the main economic power within the family in Europe. More than a quarter of working women (28\%) earn half of the total household income, and as many as $14 \%$ out-earn their partners. The distribution of couples across the three earning regimes shows important heterogeneity across Europe. 


\begin{tabular}{|c|c|c|c|c|c|c|c|c|c|c|c|}
\hline & \multicolumn{4}{|c|}{2004} & \multicolumn{4}{|c|}{2010} & \multicolumn{3}{|c|}{$\begin{array}{l}\text { Change 2004-2010 } \\
\text { (percentage points) }\end{array}$} \\
\hline & MME & $\mathrm{EE}$ & WME & $N$ & MME & $\mathrm{EE}$ & WME & $N$ & MME & $\mathrm{EE}$ & WME \\
\hline Anglo-Saxon countries: & 65.28 & 20.21 & 14.51 & 699 & 61.83 & 21.33 & 16.84 & 728 & -3.45 & 1.12 & 2.33 \\
\hline Ireland & 63.49 & 26.78 & 9.72 & 365 & 46.98 & 29.17 & 23.85 & 305 & -16.51 & 2.39 & 14.13 \\
\hline United Kingdom & 65.36 & 19.89 & 14.75 & 334 & 62.46 & 21.00 & 16.54 & 423 & -2.90 & 1.11 & 1.79 \\
\hline $\begin{array}{l}\text { Central-Eastern } \\
\text { countries: }\end{array}$ & 48.87 & 33.43 & 17.71 & 1,405 & 58.08 & 27.11 & 14.81 & 1,405 & 9.21 & -6.32 & -2.90 \\
\hline Czech Republic & 62.09 & 22.64 & 15.27 & 477 & 72.93 & 16.52 & 10.54 & 414 & 10.84 & -6.12 & -4.73 \\
\hline Hungary & 45.40 & 33.53 & 21.07 & 207 & 52.81 & 32.25 & 14.94 & 233 & 7.41 & -1.28 & -6.13 \\
\hline Poland & 44.95 & 36.90 & 18.15 & 269 & 55.42 & 28.06 & 16.52 & 275 & 10.47 & -8.84 & -1.63 \\
\hline Slovakia & 59.65 & 26.75 & 13.60 & 228 & 57.56 & 30.43 & 12.01 & 265 & -2.09 & 3.68 & -1.59 \\
\hline Slovenia & 30.77 & 50.20 & 19.03 & 247 & 30.28 & 50.00 & 19.72 & 218 & -0.49 & -0.20 & 0.69 \\
\hline Continental countries: & 61.19 & 24.06 & 14.75 & 1,176 & 52.54 & 35.24 & 12.22 & 1,140 & -8.65 & 11.18 & -2.53 \\
\hline Belgium & 58.60 & 29.57 & 11.83 & 372 & 51.93 & 37.02 & 11.05 & 389 & -6.67 & 7.45 & -0.78 \\
\hline France & 57.75 & 25.63 & 16.62 & 399 & 46.65 & 40.45 & 12.90 & 352 & -11.10 & 14.82 & -3.72 \\
\hline Netherlands & 75.32 & 15.34 & 9.35 & 405 & 74.15 & 15.38 & 10.47 & 399 & -1.17 & 0.04 & 1.12 \\
\hline German-speaking countries: & 64.61 & 22.00 & 13.39 & 882 & 69.45 & 20.27 & 10.28 & 844 & 4.84 & -1.73 & -3.11 \\
\hline Germany & 63.79 & 22.36 & 13.84 & 500 & 69.44 & 20.30 & 10.26 & 539 & 5.65 & -2.06 & -3.58 \\
\hline Switzerland & 72.33 & 18.54 & 9.13 & 382 & 69.51 & 20.00 & 10.49 & 305 & -2.82 & 1.46 & 1.36 \\
\hline Nordic countries: & 55.26 & 33.76 & 10.98 & 1,776 & 55.17 & 32.50 & 12.33 & 1,460 & -0.09 & -1.26 & 1.35 \\
\hline Denmark & 50.14 & 35.41 & 14.45 & 353 & 55.16 & 30.98 & 13.86 & 368 & 5.02 & -4.43 & -0.59 \\
\hline Finland & 53.16 & 36.60 & 10.24 & 459 & 53.51 & 35.14 & 11.35 & 370 & 0.35 & -1.46 & 1.11 \\
\hline Norway & 59.04 & 32.03 & 8.93 & 459 & 57.52 & 30.13 & 12.35 & 377 & -1.52 & -1.90 & 3.42 \\
\hline Sweden & 57.23 & 32.28 & 10.50 & 505 & 54.78 & 33.33 & 11.88 & 345 & -2.45 & 1.05 & 1.38 \\
\hline Southern European countries: & 52.47 & 37.43 & 10.10 & 553 & 47.33 & 34.68 & 17.99 & 687 & -5.14 & -2.75 & 7.89 \\
\hline Greece & 57.71 & 34.51 & 7.78 & 288 & 41.94 & 34.45 & 23.61 & 331 & -15.77 & -0.06 & 15.83 \\
\hline Spain & 51.47 & 37.99 & 10.54 & 265 & 48.26 & 34.73 & 17.01 & 356 & -3.21 & -3.26 & 6.47 \\
\hline Total & 59.47 & 26.52 & 14.02 & 6,514 & 57.99 & 28.31 & 13.71 & 6,264 & -1.48 & 1.79 & -0.31 \\
\hline
\end{tabular}

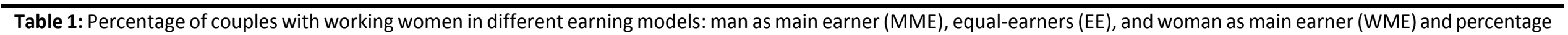
change, 2004 and 2010

Note: Percentages are weighted using design and population size weights. 
The MME arrangement declined in many European countries between 2004 and 2010. The highest declines are found in Southern European countries. In Greece, i.e. the country most heavily hit by the 2008 economic crisis, MME registered a 16 percentage point reduction (from $58 \%$ in 2004 to $42 \%$ in 2010) which went hand in hand with a 16 percentage point increase in the percentage of women as main earners. Among the 18 countries considered in this study Greece passed from holding the lowest percentage of WME in 2004 (8\%), to holding the highest percentage (24\%) in 2010 and is one of the few countries where the MME arrangement is now representative of less than half of all couples with working women. Spain, affected by the economic crisis but to a lesser extent if compared to Greece, also showed an increase in WME.

Among the Anglo-Saxon countries, Ireland was particularly affected by the economic crisis. Here, the percentage of MME dropped by 17 percentage points, from 63\% in 2004 to $47 \%$ in 2010, against a 14 percentage point increase in WME. With 24\% of WME in 2010, Ireland and Greece are the countries with the highest prevalence of WME in Europe. In the UK, the percentage of WME is quite high (17\%), but the MME arrangement is still widespread (62\%) and the prevalence of the three earning arrangements changed only marginally with respect to 2004.

The two German-speaking countries show a homogeneous distribution of couples across the three earning regimes and a clear preference for the traditional male-breadwinner model. In fact, the vast majority of couples with working women (about 70\%) are MME. In both countries, EE and WME represent only $20 \%$ and $10 \%$ of all couples, respectively. Hence, when women are working, their earnings are secondary to the man's. While Switzerland registered only marginal variations, in Germany the percentage of MME registered an increase between 2004 and 2010.

Among Continental countries, France and Belgium experienced a sharp decline in MME between 2004 and 2010 against an increase in EE, which places these two countries at the top of the ranking, after Slovenia, for the prevalence of EE which accounts for $40 \%$ and $37 \%$ of all couples, respectively. The prevalence of WME is equal to 13\% in France and 11\% in Belgium. The Netherlands, where part-time work for women is particularly diffused, holds the highest prevalence of MEM, equal to 74\% of all couples with working women. It also holds the lowest prevalence of EE (15\%) and WME (10\%) in the sample. 
Among the Central and Eastern European countries, Czech Republic is characterized by a very high prevalence of MME (73\%). Consequently, the prevalence of EE and WME (17\% and $11 \%$ ) is among the lowest in Europe. The MME arrangement accounts for about 55\% in Slovakia, Poland and Hungary, EE for about 30\% and WME between 12\% and 17\%. Of all countries in our sample, Slovenia is the one where the EE arrangement is the most widespread, accounting for $50 \%$ of all couples. The prevalence of WME is also very high compared to other countries (21\%), while the MME regime represents only 30\% of all couples. Poland, Czech Republic and Hungary registered an increase in MME between 2004 and 2010, mainly driven by a reduction in EE. EE increased slightly in Slovakia, while no change occurred in Slovenia.

The Nordic countries show a high degree of homogeneity in the distribution of couples into the three earning regimes. MME account for slightly more than one in two couples with working women, EE for slightly more than one in three, and MME for 11-14\%. Only marginal variations are recorded between 2004 and 2010: in Norway, the percentage of WME slightly increased, while in Denmark in the percentage of MME increased, mainly driven by a decline in EE.

Descriptive statistics show that, in the second half of the 2000s, the economic power of women within the couple increased in Southern and Continental Europe and Ireland, declined in Central and Eastern Europe, Germany and Denmark and did not change much in the rest of the Nordic countries, Slovenia, Netherlands, Switzerland and UK. Hence, from the descriptive analyses we cannot find a common pattern across the 18 countries analysed but we do find some homogeneity within our classification of countries into groups.

\section{RESULTS FROM MULTINOMIAL LOGISTIC REGRESSIONS}

Tables 2 to 8 show results from multinomial logistic models for each country group. We identify the key characteristics common to all country groups, as well as country-group specificities associated with the three earning arrangements in couples with working women. In particular, we report the average marginal effects (AME), i.e. the effect of a change (from 0 to 1 ) in each explanatory (categorical) variable on the probability of observing each of the three earning models, controlling for the other variables. 
Results show that men are more likely to report being in the MME arrangement and less likely to report being in the EE or WME arrangement compared to women. The marginal effect of being a man vs. a woman is not statically significant on the EE and WME arrangements in Continental and Central-Eastern European countries.

Similarly to what has been found in previous studies, the age effect is, in general, scarcely relevant. The woman's birth cohort is not significant in explaining the couple's earning arrangement. The younger cohort (1970-1986) shows a positive marginal effect on EE in comparison to those born in 1960-69 in Continental countries and negative marginal effect on WME in Central-Eastern European countries. We find only partial support for the hypothesis that the age difference between partners explains different earning arrangements. If the woman is younger (vs. of the same age), the MME arrangement is more likely in German-speaking, Continental, and Central-Eastern European countries. Similarly, if the woman is older, the MME arrangement is less likely in all the country groups except German-speaking and Southern European countries. Only for Central-Eastern European countries we find that if the woman is older, she has an increased probability of being the main earner.

Results show a heterogeneous picture of the effect of her educational level. In Germanspeaking and Nordic countries it is possible to identify two distinct patterns: couples with higheducated as well as low-educated women are more likely to be in the WME arrangement and less likely to be in the MME arrangement than couples with medium-educated women. Low-educated women have a higher probability of being in the MME arrangement in Anglo-Saxon and Southern European countries. Similarly, high-educated women have a lower probability of being in the MME arrangement in Central-Eastern European countries. In Continental countries, instead, the educational attainment of women is unrelated to the earning arrangement. The educational difference between partners also matters. In Anglo-Saxon countries, women and men with higher education than their partners are more likely to be main earners compared to equally educated partners, while the educational composition of the couple has no effect for equal earners. In other country groups, returns from education are lower for women than for men. For Continental, Central-Eastern European, German-speaking and Nordic countries, if the woman is less (vs. equally) educated, the EE and WME arrangements are less likely and the MME arrangement is more likely. However, if the woman is more educated than her partner, the probability of being in the EE arrangement is the same as for couples with equally educated partners. The educational difference among partners is only marginally significant in Southern 
European countries suggesting that the returns to education are generally low in this group, for both women and men.

As expected, employment status of both partners matters. In all country groups, when the man is unemployed or works part-time (vs. full-time), the probability of observing the MME arrangement dramatically decreases (-37\% in Central-Eastern European countries and between $20-30 \%$ in all other groups) while the probability of observing the WME arrangement increases (44\% in Central-Eastern countries and between $24-36 \%$ in all other groups). In Continental, Southern and Central-Eastern European countries, the probability of observing the EE arrangement also decreases. For German-speaking, Northern and Anglo-Saxon countries, instead, the probability of observing the EE arrangement is independent of the man's employment status. If the woman works part time (vs. full-time) it is more likely to observe the MME and less likely to observe the EE and WME arrangements.

In all country groups, the presence of children in the household is associated with the couple’s earning arrangement. In Anglo-Saxon countries, having one child (vs. none) increases the probability of observing the MME arrangement by 0.097 and reduces the probability of observing the EE arrangement by 0.073. Similarly, in Central-Eastern European countries, having one child reduces the probability of observing the EE arrangement. Having two or more children (vs. none) increases the probability of observing the MME arrangement in all groups, except for Southern European countries. In Anglo-Saxon countries, the marginal effect of having two or more children (vs. none) is stronger than the effect of having only one child (15.5\% vs. 9.7\% in the MME arrangement, and $-11.4 \%$ vs. $-7.3 \%$ in the EE arrangement). The presence of a young child in the household is not important, except for the negative (but it is significant only at the $10 \%$ level) effect on the likelihood of being in the MME and EE arrangements in Southern European and Nordic countries. Interestingly, the presence of children is not related to the WME arrangement (except in Southern European countries where we find a negative but barely significant effect). When interpreting these results, it has to be noted that we refer to the sample of couples with working women and hence the presence of (young) children, which is associated with the decision to work, need not necessarily be associated with the observed earning arrangement. $^{5}$

\footnotetext{
${ }^{5}$ Additional results (not shown) run on the sample of all couples, including women who are not employed suggest that the presence of children, especially if young, is highly negative associated with the likelihood of providing an equal or the highest share of household income vs. providing the lowest share or no income.
} 
Cohabitation (as opposed to marriage) is positively associated with the EE arrangement only in Anglo-Saxon, Central-Eastern European and German-speaking countries, and negatively associated with MME only in Central-Eastern European, German-speaking and Nordic countries. The WME arrangement is not influenced by the cohabitation vs. marriage status.

With respect to couples whose household income lies in the three middle quintiles, those whose income lies in the bottom first, i.e. the poorest, have a higher probability of being in the WME arrangement only in Central-Eastern European countries (0.077), a lower probability of being in the MME arrangement in Continental (0.102) and Nordic countries (0.143). On the other hand, couples whose household income lies in the top fifth, i.e. the richest, quintile, have a higher probability of being in the MME arrangement and a lower probability of being in the EE arrangement in Central-Eastern European (0.057 and -0.088, respectively), German-speaking (0.082 and -0.074) and Nordic (0.079 and -0.088) countries. For Continental countries, we find a peculiar effect. Couples whose household income lies in the richest quintile have a higher (though barely significant) probability of being in the WME arrangement (0.032). For AngloSaxon and Southern European countries, instead, household income has no effect on the earning arrangement.

The effects for the country and year dummies and their interaction, included in the six regression models presented in Tables 2 to 7 , are reported in Table 8 in the form of odds ratios. ${ }^{6}$ For the Anglo-Saxon countries, after controlling for the other variables, the WME arrangement is more likely in United Kingdom than in Ireland (o.r. 2.53), and in 2010 than in 2004 (o.r. 2.25). On the other hand, living in UK in 2010 reduced the odds of being in the WME arrangement. As for the joint effect of time and place, for Continental countries we find a significant increase in the odds of being in the EE vs. MME arrangement in France (compared to the Netherlands) between 2004 and 2010. Belgium shows a higher likelihood of having couples in the EE arrangement (vs. MME) than the Netherlands, other things being equal, but shows no change between 2004 and 2010. For Central-Eastern European countries we do not find any significant increased likelihood of being in the EE nor the WME arrangements during the economic crisis. Among the countries in this group, Slovenia shows higher odds of observing the EE and WME arrangements than Slovakia. Hungary also shows higher odds of observing the WME

\footnotetext{
${ }^{6}$ These are reported separately because marginal effects for the interaction between country and year cannot be estimated.
} 
arrangement, while we do not find any difference between Slovakia and the other countries in the group, controlling for the other variables in the model. For German-speaking countries we find no change in earning arrangements between 2004 and 2010. In Germany the odds of being in the EE and WME arrangements are higher than Switzerland. Among the Nordic countries, only in Sweden do we find a significant increase in the WME arrangements during the economic crisis. Sweden and Denmark show higher odds of observing the WME arrangement compared to Norway. In Southern European countries we find a sharp increase in the probability of living in the WME arrangement (vs. MME) in 2010 than 2004. The odds of being WME are almost five times higher during the economic crisis with respect to the pre-crisis period, other things being equal, the effect of the crisis on the probability of observing the WME arrangement is lower in Spain than in Greece. ${ }^{7}$

\footnotetext{
${ }^{7}$ The interaction between Spain and the year 2010 is statistically significant, but the main effect of the country dummy for Spain is not statically different from the reference category Greece.
} 


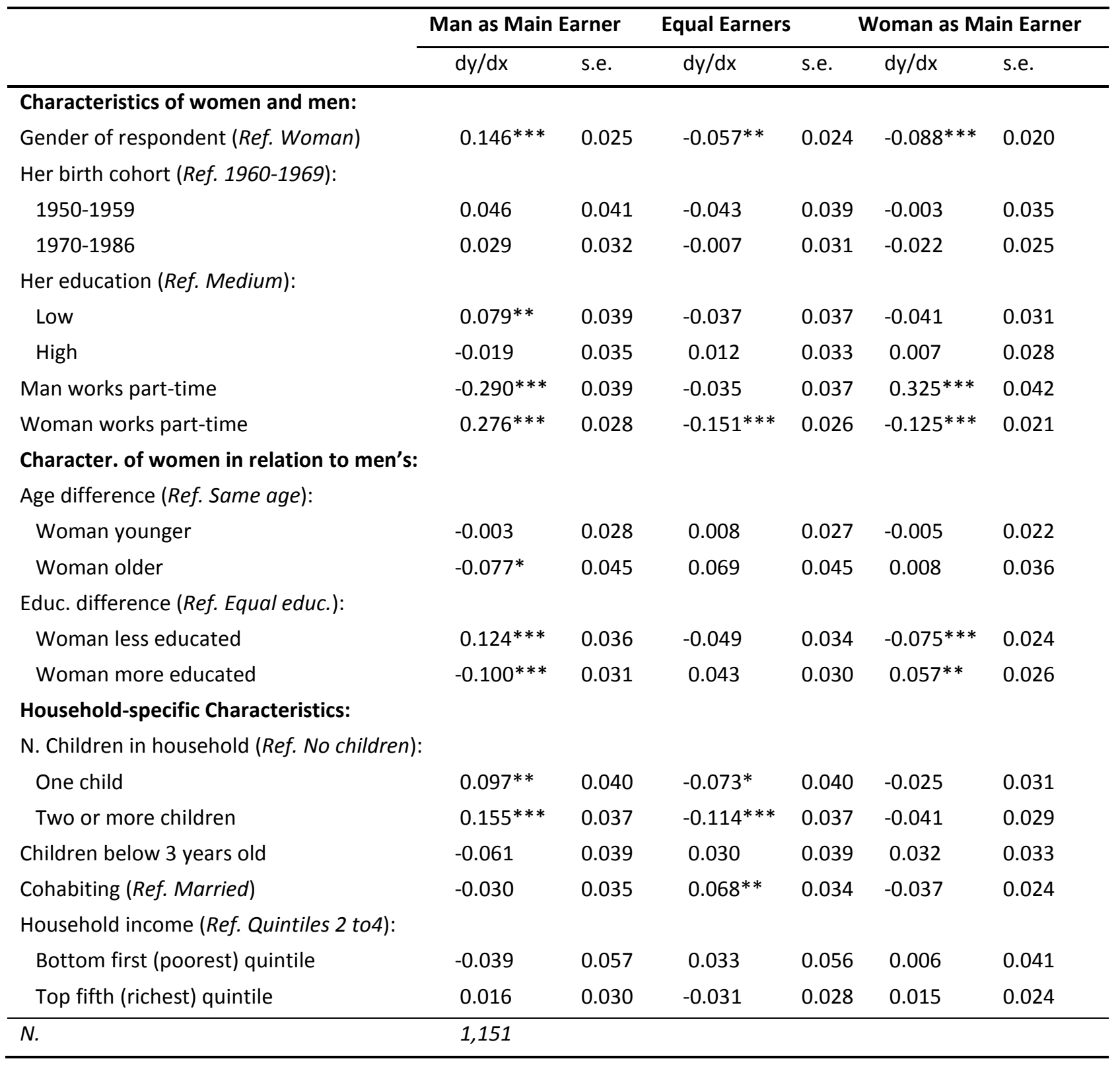

p-value: $* * *<0.01 ; * *<0.05 ; *<0.1$.

Table 2: Multinomial logistic regression of earning arrangements, Anglo-Saxon Countries (Average Marginal Effects)

Note: The multinomial logistic model includes controls for country dummies, UK and Ireland (ref.), survey year, 2010 vs. 2004 (ref.) and their interactions (see table 8). 


\begin{tabular}{|c|c|c|c|c|c|c|}
\hline & \multicolumn{2}{|c|}{ Man as Main Earner } & \multicolumn{2}{|c|}{ Equal Earners } & \multicolumn{2}{|c|}{$\begin{array}{l}\text { Woman as Main } \\
\text { Earner }\end{array}$} \\
\hline & $\mathrm{dy} / \mathrm{dx}$ & s.e. & $d y / d x$ & s.e. & $\mathrm{dy} / \mathrm{dx}$ & s.e. \\
\hline \multicolumn{7}{|l|}{ Characteristics of women and men: } \\
\hline Gender of respondent (Ref. Woman) & $0.067^{* * *}$ & 0.021 & $-0.064^{* * *}$ & 0.020 & -0.003 & 0.015 \\
\hline \multicolumn{7}{|l|}{ Her birth cohort (Ref. 1960-1969): } \\
\hline $1950-1959$ & 0.014 & 0.032 & -0.021 & 0.031 & 0.007 & 0.025 \\
\hline 1970-1986 & 0.035 & 0.025 & 0.008 & 0.024 & $-0.043 * *$ & 0.018 \\
\hline \multicolumn{7}{|l|}{ Her education (Ref. Medium): } \\
\hline Low & -0.060 & 0.045 & 0.015 & 0.043 & 0.045 & 0.037 \\
\hline High & $-0.068 * *$ & 0.029 & 0.043 & 0.029 & 0.025 & 0.022 \\
\hline Man works part-time & $-0.374 * * *$ & 0.030 & $-0.066^{* *}$ & 0.034 & $0.441^{* * *}$ & 0.038 \\
\hline Woman works part-time & $0.168^{* * *}$ & 0.033 & $-0.088^{* * *}$ & 0.031 & $-0.080 * * *$ & 0.019 \\
\hline \multicolumn{7}{|l|}{$\begin{array}{l}\text { Character. of women in relation to } \\
\text { men's: }\end{array}$} \\
\hline \multicolumn{7}{|l|}{ Age difference (Ref. Same age): } \\
\hline Woman younger & $0.037^{*}$ & 0.022 & -0.024 & 0.021 & -0.013 & 0.016 \\
\hline Woman older & $-0.089 *$ & 0.046 & 0.014 & 0.045 & $0.075^{* *}$ & 0.038 \\
\hline \multicolumn{7}{|l|}{ Educ. difference (Ref. Equal educ.): } \\
\hline Woman less educated & $0.122^{* * *}$ & 0.033 & $-0.067^{* *}$ & 0.032 & $-0.055^{* * *}$ & 0.020 \\
\hline Woman more educated & $-0.079 * *$ & 0.032 & -0.034 & 0.030 & $0.113^{* * *}$ & 0.029 \\
\hline \multicolumn{7}{|l|}{ Household-specific Characteristics: } \\
\hline \multicolumn{7}{|c|}{ N. Children in household (Ref. No children): } \\
\hline One child & 0.044 & 0.033 & $-0.058^{*}$ & 0.033 & 0.014 & 0.023 \\
\hline Two or more children & $0.053^{*}$ & 0.031 & $-0.082 * * *$ & 0.031 & 0.029 & 0.022 \\
\hline Children below 3 years old & -0.011 & 0.045 & -0.002 & 0.042 & 0.013 & 0.034 \\
\hline Cohabiting (Ref. Married) & $-0.094 * * *$ & 0.036 & $0.059^{*}$ & 0.035 & 0.035 & 0.028 \\
\hline \multicolumn{7}{|l|}{ Household income (Ref. Quintiles 2 to4): } \\
\hline Bottom first (poorest) quintile & -0.040 & 0.045 & -0.037 & 0.041 & $0.077^{* *}$ & 0.033 \\
\hline Top fifth (richest) quintile & $0.057^{* *}$ & 0.027 & $-0.088^{* * *}$ & 0.026 & 0.031 & 0.021 \\
\hline & 1,936 & & & & & \\
\hline
\end{tabular}

p-value: $* * *<0.01 ; * *<0.05 ; *<0.1$

Table 3: Multinomial logistic regression of earning arrangements, Central-Eastern European Countries (Average Marginal Effects)

Note: The multinomial logistic model includes controls for country dummies, Hungary, Slovenia, Poland, Czech Republic and Slovakia (ref.), survey year, 2010 vs. 2004 (ref.), and their interactions (see table 8). 


\begin{tabular}{|c|c|c|c|c|c|c|}
\hline & \multicolumn{2}{|c|}{ Man as Main Earner } & \multicolumn{2}{|c|}{ Equal Earners } & \multicolumn{2}{|c|}{ Woman as Main Earner } \\
\hline & $d y / d x$ & s.e. & $\mathrm{dy} / \mathrm{dx}$ & s.e. & $\mathrm{dy} / \mathrm{dx}$ & s.e. \\
\hline \multicolumn{7}{|l|}{ Characteristics of women and men: } \\
\hline Gender of respondent (Ref. Woman) & $0.068 * * *$ & 0.020 & -0.006 & 0.019 & $-0.062 * * *$ & 0.014 \\
\hline \multicolumn{7}{|l|}{ Her birth cohort (Ref. 1960-1969): } \\
\hline $1950-1959$ & 0.017 & 0.032 & -0.019 & 0.030 & 0.002 & 0.024 \\
\hline $1970-1986$ & -0.034 & 0.025 & $0.057^{* *}$ & 0.024 & -0.023 & 0.018 \\
\hline \multicolumn{7}{|l|}{ Her education (Ref. Medium): } \\
\hline Low & -0.012 & 0.034 & -0.010 & 0.034 & 0.022 & 0.028 \\
\hline High & -0.022 & 0.024 & 0.033 & 0.023 & -0.011 & 0.017 \\
\hline Man works part-time & $-0.195 * * *$ & 0.034 & $-0.053^{*}$ & 0.031 & $0.248^{* * *}$ & 0.034 \\
\hline Woman works part-time & $0.273^{* * *}$ & 0.023 & $-0.185^{* * *}$ & 0.022 & $-0.088 * * *$ & 0.016 \\
\hline \multicolumn{7}{|l|}{$\begin{array}{l}\text { Character. of women in relation to } \\
\text { men's: } \\
\text { Age difference (Ref. Same age): }\end{array}$} \\
\hline Woman younger & $0.040^{*}$ & 0.021 & -0.026 & 0.020 & -0.015 & 0.015 \\
\hline Woman older & $-0.024^{*}$ & 0.041 & 0.011 & 0.040 & 0.013 & 0.028 \\
\hline \multicolumn{7}{|l|}{ Educ. difference (Ref. Equal educ.): } \\
\hline Woman less educated & $0.106^{* * *}$ & 0.030 & $-0.063 * *$ & 0.028 & $-0.043 * *$ & 0.017 \\
\hline Woman more educated & $-0.112^{* * *}$ & 0.025 & 0.027 & 0.024 & $0.085^{* * *}$ & 0.021 \\
\hline \multicolumn{7}{|l|}{ Household-specific Characteristics: } \\
\hline \multicolumn{7}{|l|}{$\begin{array}{l}\text { N. Children in household (Ref. No } \\
\text { children): }\end{array}$} \\
\hline One child & 0.046 & 0.031 & -0.047 & 0.030 & 0.001 & 0.022 \\
\hline Two or more children & $0.081^{* *}$ & 0.028 & $-0.060 * *$ & 0.027 & -0.021 & 0.020 \\
\hline Children below 3 years old & -0.042 & 0.029 & 0.041 & 0.029 & 0.001 & 0.022 \\
\hline Cohabiting (Ref. Married) & -0.041 & 0.026 & 0.031 & 0.024 & 0.010 & 0.019 \\
\hline \multicolumn{7}{|l|}{$\begin{array}{l}\text { Household income (Ref. Quintiles } 2 \\
\text { to4): }\end{array}$} \\
\hline Bottom first (poorest) quintile & $-0.102 * *$ & 0.051 & 0.052 & 0.052 & 0.051 & 0.036 \\
\hline Top fifth (richest) quintile & -0.007 & 0.024 & -0.025 & 0.022 & $0.032 *$ & 0.018 \\
\hline & 2,035 & & & & & \\
\hline
\end{tabular}

p-value: ${ }^{* *}<0.01 ; * *<0.05 ; *<0.1$.

Table 4: Multinomial logistic regression of earning arrangements, Continental Countries (Average Marginal Effects) Note: The multinomial logistic model includes controls for country dummies, Belgium, France and The Netherlands (ref.), survey year, 2010 vs. 2004 (ref.), and their interactions (see table 8). 


\begin{tabular}{|c|c|c|c|c|c|c|}
\hline & \multicolumn{2}{|c|}{$\begin{array}{l}\text { Man as Main } \\
\text { Earner }\end{array}$} & \multicolumn{2}{|c|}{ Equal Earners } & \multicolumn{2}{|c|}{$\begin{array}{c}\text { Woman as Main } \\
\text { Earner }\end{array}$} \\
\hline & $\mathrm{dy} / \mathrm{dx}$ & s.e. & $d y / d x$ & s.e. & $\mathrm{dy} / \mathrm{dx}$ & \\
\hline \multicolumn{7}{|l|}{ Characteristics of women and men: } \\
\hline Gender of respondent (Ref. Woman) & $0.091 * * *$ & 0.021 & $-0.060 * * *$ & 0.020 & $-0.031 * *$ & 0.016 \\
\hline \multicolumn{7}{|l|}{ Her birth cohort (Ref. 1960-1969): } \\
\hline 1950-1959 & 0.034 & 0.032 & -0.019 & 0.031 & -0.015 & 0.024 \\
\hline 1970-1986 & 0.026 & 0.025 & -0.008 & 0.024 & -0.018 & 0.019 \\
\hline \multicolumn{7}{|l|}{ Her education (Ref. Medium): } \\
\hline Low & $-0.184 * * *$ & 0.046 & 0.022 & 0.047 & $0.161^{* * *}$ & 0.052 \\
\hline High & $-0.067 * * *$ & 0.026 & 0.029 & 0.025 & $0.038 * *$ & 0.018 \\
\hline Man works part-time & $-0.315 * * *$ & 0.036 & -0.018 & 0.035 & $0.333 * * *$ & 0.039 \\
\hline Woman works part-time & $0.335^{* * *}$ & 0.024 & $-0.208 * * *$ & 0.023 & $-0.127 * * *$ & 0.017 \\
\hline \multicolumn{7}{|c|}{ Character. of women in relation to men's: } \\
\hline \multicolumn{7}{|l|}{ Age difference (Ref. Same age): } \\
\hline Woman younger & $0.046 * *$ & 0.022 & -0.022 & 0.021 & -0.025 & 0.017 \\
\hline Woman older & 0.039 & 0.042 & -0.003 & 0.040 & -0.037 & 0.028 \\
\hline \multicolumn{7}{|l|}{ Educ. difference (Ref. Equal educ.): } \\
\hline Woman less educated & $0.132 * * *$ & 0.027 & $-0.068 * * *$ & 0.025 & $-0.065 * * *$ & 0.018 \\
\hline Woman more educated & -0.049 & 0.032 & 0.001 & 0.030 & $0.048^{*}$ & 0.026 \\
\hline \multicolumn{7}{|l|}{ Household-specific Characteristics: } \\
\hline \multicolumn{7}{|c|}{ N. Children in household (Ref. No children): } \\
\hline One child & 0.003 & 0.030 & 0.016 & 0.029 & -0.019 & 0.022 \\
\hline Two or more children & $0.055^{* *}$ & 0.029 & -0.039 & 0.027 & -0.016 & 0.021 \\
\hline Children below 3 years old & -0.035 & 0.043 & -0.001 & 0.043 & 0.035 & 0.037 \\
\hline Cohabiting (Ref. Married) & $-0.126 * * *$ & 0.031 & $0.107 * * *$ & 0.031 & 0.019 & 0.022 \\
\hline \multicolumn{7}{|l|}{ Household income (Ref. Quintiles 2 to 4): } \\
\hline Bottom first (poorest) quintile & -0.067 & 0.048 & 0.043 & 0.047 & 0.024 & 0.033 \\
\hline \multirow[t]{2}{*}{ Top fifth (richest) quintile } & $0.082 * * *$ & 0.024 & $-0.074 * * *$ & 0.022 & -0.009 & 0.018 \\
\hline & 1,441 & & & & & \\
\hline
\end{tabular}

p-value: $* * *<0.01 ; * *<0.05 ; *<0.1$

Table 5: Multinomial logistic regression of earning arrangements, German-speaking Countries (Average Marginal Effects)

Note: The multinomial logistic model includes controls for country dummies, Germany, and Switzerland (ref.), survey year, 2010 vs. 2004 (ref.), and their interactions (see table 8). 


\begin{tabular}{|c|c|c|c|c|c|c|}
\hline & \multicolumn{2}{|c|}{$\begin{array}{l}\text { Man as Main } \\
\text { Earner }\end{array}$} & \multicolumn{2}{|c|}{ Equal Earners } & \multicolumn{2}{|c|}{$\begin{array}{c}\text { Woman as Main } \\
\text { Earner }\end{array}$} \\
\hline & $\mathrm{dy} / \mathrm{dx}$ & s.e. & $\mathrm{dy} / \mathrm{dx}$ & s.e. & $d y / d x$ & s.e. \\
\hline \multicolumn{7}{|l|}{ Characteristics of women and men: } \\
\hline Gender of respondent (Ref. Woman) & $0.105^{* * *}$ & 0.018 & $-0.066 * * *$ & 0.018 & $-0.039 * * *$ & 0.012 \\
\hline \multicolumn{7}{|l|}{ Her birth Cohort (Ref. 1960-1969): } \\
\hline 1950-1959 & 0.041 & 0.027 & -0.034 & 0.026 & -0.007 & 0.018 \\
\hline $1970-1986$ & 0.014 & 0.022 & 0.006 & 0.021 & -0.020 & 0.014 \\
\hline \multicolumn{7}{|l|}{ Her education (Ref. Medium): } \\
\hline Low & $-0.121 * * *$ & 0.038 & -0.009 & 0.038 & $0.130 * * *$ & 0.037 \\
\hline High & $-0.050 * *$ & 0.022 & -0.002 & 0.021 & $0.052 * * *$ & 0.013 \\
\hline Man works part-time & $-0.207 * * *$ & 0.032 & -0.031 & 0.033 & $0.239 * * *$ & 0.032 \\
\hline Woman works part-time & $0.262^{* * *}$ & 0.020 & $-0.180 * * *$ & 0.019 & $-0.082^{* * *}$ & 0.011 \\
\hline \multicolumn{7}{|c|}{ Character. of women in relation to men's: } \\
\hline \multicolumn{7}{|l|}{ Age difference (Ref. Same age): } \\
\hline Woman younger & 0.021 & 0.019 & -0.015 & 0.018 & -0.007 & 0.012 \\
\hline Woman older & $-0.075^{* *}$ & 0.032 & 0.038 & 0.032 & 0.037 & 0.023 \\
\hline \multicolumn{7}{|l|}{ Educ. difference (Ref. Equal educ.): } \\
\hline Woman less educated & $0.145^{* * *}$ & 0.028 & $-0.064 * *$ & 0.028 & $-0.081 * * *$ & 0.017 \\
\hline Woman more educated & $-0.091 * * *$ & 0.022 & 0.020 & 0.022 & $0.071 * * *$ & 0.018 \\
\hline \multicolumn{7}{|l|}{ Household-specific Characteristics: } \\
\hline \multicolumn{7}{|c|}{ N. Children in household (Ref. No children): } \\
\hline One child & -0.002 & 0.027 & -0.002 & 0.027 & 0.004 & 0.019 \\
\hline Two or more children & $0.053^{* *}$ & 0.027 & $-0.039 *$ & 0.024 & -0.014 & 0.016 \\
\hline Children below 3 years old & 0.030 & 0.024 & $-0.045^{*}$ & 0.026 & 0.016 & 0.019 \\
\hline Cohabiting (Ref. Married) & $-0.043^{*}$ & 0.027 & 0.028 & 0.022 & 0.016 & 0.015 \\
\hline \multicolumn{7}{|l|}{ Household income (Ref. Quintiles 2 to 4): } \\
\hline Bottom first (poorest) quintile & $-0.143^{* *}$ & 0.058 & 0.082 & 0.062 & 0.062 & 0.045 \\
\hline Top fifth (richest) quintile & $0.079 * * *$ & 0.020 & $-0.088 * * *$ & 0.020 & 0.009 & 0.014 \\
\hline & 2,843 & & & & & \\
\hline
\end{tabular}

p-value: ${ }^{* * *}<0.01 ; * *<0.05 ;{ }^{*}<0.1$.

Table 6: Multinomial logistic regression of earning arrangements, Nordic Countries (Average Marginal Effects) Note: The multinomial logistic model includes controls for country dummies, Sweden, Denmark, Finland and Norway (ref.), survey year, 2010 vs. 2004 (ref.), and their interactions (see table 8). 


\begin{tabular}{|c|c|c|c|c|c|c|}
\hline & \multicolumn{2}{|c|}{$\begin{array}{l}\text { Man as Main } \\
\text { Earner }\end{array}$} & \multicolumn{2}{|c|}{ Equal Earners } & \multicolumn{2}{|c|}{$\begin{array}{c}\text { Woman as Main } \\
\text { Earner }\end{array}$} \\
\hline & $\mathrm{dy} / \mathrm{dx}$ & s.e. & $\mathrm{dy} / \mathrm{dx}$ & s.e. & $\mathrm{dy} / \mathrm{dx}$ & s.e. \\
\hline \multicolumn{7}{|l|}{ Characteristics of women and men: } \\
\hline Gender of respondent (Ref. Woman) & $0.184 * * *$ & 0.031 & $-0.140 * * *$ & 0.031 & $-0.043 * *$ & 0.021 \\
\hline \multicolumn{7}{|l|}{ Her birth Cohort (Ref. 1960-1969): } \\
\hline 1950-1959 & 0.009 & 0.060 & -0.060 & 0.058 & 0.051 & 0.050 \\
\hline 1970-1986 & 0.008 & 0.037 & 0.002 & 0.037 & -0.009 & 0.026 \\
\hline \multicolumn{7}{|l|}{ Her education (Ref. Medium): } \\
\hline Low & $0.081^{*}$ & 0.046 & -0.038 & 0.045 & -0.042 & 0.029 \\
\hline High & -0.065 & 0.041 & 0.035 & 0.041 & 0.030 & 0.029 \\
\hline Man works part-time & $-0.247 * * *$ & 0.040 & $-0.114 * * *$ & 0.043 & $0.361 * * *$ & 0.045 \\
\hline Woman works part-time & $0.272 * * *$ & 0.035 & $-0.192 * * *$ & 0.034 & $-0.079 * * *$ & 0.022 \\
\hline \multicolumn{7}{|c|}{ Character. of women in relation to men's: } \\
\hline \multicolumn{7}{|l|}{ Age difference (Ref. Same age): } \\
\hline Woman younger & 0.034 & 0.033 & -0.001 & 0.032 & -0.034 & 0.023 \\
\hline Woman older & 0.013 & 0.078 & -0.022 & 0.077 & 0.009 & 0.055 \\
\hline \multicolumn{7}{|l|}{ Educ. difference (Ref. Equal educ.): } \\
\hline Woman less educated & 0.016 & 0.046 & -0.027 & 0.046 & 0.011 & 0.034 \\
\hline Woman more educated & -0.044 & 0.037 & -0.001 & 0.037 & $0.044^{*}$ & 0.027 \\
\hline \multicolumn{7}{|l|}{ Household-specific Characteristics: } \\
\hline \multicolumn{7}{|c|}{ N. Children in household (Ref. No children): } \\
\hline One child & 0.053 & 0.045 & -0.008 & 0.045 & -0.045 & 0.033 \\
\hline Two or more children & 0.053 & 0.042 & 0.003 & 0.043 & $-0.056^{*}$ & 0.031 \\
\hline Children below 3 years old & $-0.087^{*}$ & 0.048 & 0.081 & 0.050 & 0.006 & 0.036 \\
\hline Cohabiting (Ref. Married) & -0.059 & 0.052 & 0.087 & 0.054 & -0.027 & 0.031 \\
\hline \multicolumn{7}{|l|}{ Household income (Ref. Quintiles 2 to 4): } \\
\hline Bottom first (poorest) quintile & -0.064 & 0.054 & 0.017 & 0.057 & 0.047 & 0.043 \\
\hline \multirow[t]{2}{*}{ Top fifth (richest) quintile } & 0.058 & 0.039 & -0.058 & 0.038 & 0.000 & 0.028 \\
\hline & 897 & & & & & \\
\hline
\end{tabular}

p-value: ${ }^{* *}<0.01 ; * *<0.05 ;{ }^{*}<0.1$

Table 7: Multinomial logistic regression of earning arrangements, Southern European countries (Average Marginal Effects)

Note: The multinomial logistic model includes controls for country dummies, Greece and Spain (ref.), survey year, 2010 vs. 2004 (ref.), and their interactions (see table 8). 


\begin{tabular}{|c|c|c|c|c|}
\hline & \multicolumn{2}{|c|}{$\begin{array}{c}\text { Equal Earners vs. } \\
\text { Man as Main } \\
\text { Earner }\end{array}$} & \multicolumn{2}{|c|}{$\begin{array}{l}\text { Woman as Main } \\
\text { Earner vs. } \\
\text { Man as Main } \\
\text { Earner }\end{array}$} \\
\hline & odds & s.e. & odds & s.e. \\
\hline \multicolumn{5}{|c|}{ Anglo-Saxon Countries (Ref. Ireland) } \\
\hline 2010 (Ref. 2004) & 1.158 & 0.289 & $2.531 * *$ & 0.816 \\
\hline United Kingdom & 0.738 & 0.172 & $2.252 * *$ & 0.688 \\
\hline United Kingdom *2010 & 0.722 & 0.236 & $0.296 * *$ & 0.119 \\
\hline \multicolumn{5}{|c|}{ Continental Countries (Ref. The Netherlands) } \\
\hline 2010 (Ref. 2004) & 0.989 & 0.221 & 1.238 & 0.346 \\
\hline Belgium & $1.818^{* *}$ & 0.392 & 1.609 & 0.453 \\
\hline Belgium*2010 & 1.106 & 0.322 & 0.729 & 0.278 \\
\hline France & 1.190 & 0.294 & 1.473 & 0.469 \\
\hline France*2010 & $1.960 *$ & 0.603 & 0.900 & 0.360 \\
\hline \multicolumn{5}{|c|}{ Central-Eastern Eur. Countries (Ref. Slovakia) } \\
\hline 2010 (Ref. 2004) & 0.815 & 0.249 & 1.316 & 0.532 \\
\hline Hungary & 1.369 & 0.382 & $2.132^{*}$ & 0.768 \\
\hline Hungary*2010 & 0.889 & 0.356 & 0.494 & 0.258 \\
\hline Slovenia & $2.770 * * *$ & 0.782 & $2.531^{*}$ & 0.970 \\
\hline Slovenia*2010 & 1.209 & 0.485 & 1.058 & 0.561 \\
\hline Poland & 1.639 & 0.425 & 1.824 & 0.644 \\
\hline Poland*2010 & 0.584 & 0.224 & 0.412 & 0.210 \\
\hline Czech Rep. & 0.667 & 0.172 & 1.325 & 0.461 \\
\hline Czech Rep. $* 2010$ & 0.799 & 0.301 & 0.436 & 0.218 \\
\hline \multicolumn{5}{|c|}{ German-speaking Countries (Ref. Switzerland) } \\
\hline 2010 (Ref. 2004) & 1.363 & 0.330 & 1.225 & 0.391 \\
\hline Germany & $1.855^{* *}$ & 0.419 & $2.404 * *$ & 0.692 \\
\hline Germany*2010 & 0.581 & 0.179 & 0.540 & 0.216 \\
\hline \multicolumn{5}{|c|}{ Nordic Countries (Ref. Norway) } \\
\hline 2010 (Ref. 2004) & 0.787 & 0.133 & 1.120 & 0.288 \\
\hline Sweden & 1.504 & 0.345 & $6.182 * * *$ & 2.442 \\
\hline Sweden*2010 & 0.924 & 0.263 & $0.176 * * *$ & 0.082 \\
\hline Denmark & 1.294 & 0.222 & $2.055^{* *}$ & 0.522 \\
\hline Denmark*2010 & 0.991 & 0.244 & 0.631 & 0.224 \\
\hline Finland & 0.853 & 0.134 & 0.852 & 0.216 \\
\hline Finland*2010 & 1.168 & 0.283 & 0.868 & 0.322 \\
\hline \multicolumn{5}{|c|}{ Southern European Countries (Ref. Greece) } \\
\hline 2010 (Ref. 2004) & 1.071 & 0.256 & $4.816 * * *$ & 1.822 \\
\hline Spain & 1.274 & 0.309 & 2.194 & 0.918 \\
\hline Spain*2010 & 0.625 & 0.199 & $0.243 * *$ & 0.120 \\
\hline
\end{tabular}

Table 8: Multinomial logistic regression of earning arrangements: effects of time and place (Odds ratios estimates)

Note: We present results from models estimated or each country group separately. All controls in Tables 2-7 are included. 


\section{DISCUSSION}

This paper studied the distribution of couples with working women into different earning arrangements across 18 European countries (grouped into six clusters on the basis of their welfare arrangements) using repeated cross-national survey data for the mid and late 2000s. We identified the key characteristics of women, men, and their households associated with three earning arrangements where, alternatively, the man is the main earner, the women is the main earner, or both partners contribute equally to the household income.

Results show that couples where the woman contributes an equal or the highest share of the household income tend to have similar characteristics.

First, self-reported measures of who is the main earner in the household are not gender neutral. Male respondents tend to report that they contribute the largest share, while female respondents tend to report that they contribute an equal or the largest share. Even in the Nordic countries, that score high in terms of public and domestic gender equality, we find a gender effect.

Second, the earning arrangement is associated with the employment status of both partners. Intuitively, couples where the woman works part-time are less likely to depart from the MME arrangement if compared to couples where the woman works full-time. A similar result is found for couples where the man works part-time or is not employed. In this case, there is a positive effect on the likelihood of observing the WME arrangement and a negative effect of observing the MME or the EE arrangements. However, in German-speaking, Nordic and Anglo-Saxon countries, the EE arrangement is independent of the man's employment status; this result likely depends on the fact that the man may still contribute to the household income through e.g. unemployment or social benefits, income from investments or other sources, although with our survey data we are not able to investigate this further.

Third, having children in the household is generally negatively associated with equal earnings, while we find no effect on the likelihood of women being the main 
earner. While it is well known from previous literature that, especially in Germanspeaking and Southern European countries, the presence of children, especially if young, negatively correlates with the decision to work for women, once the decision to work has been made, the presence of children does not necessarily mean that the economic role of women is only supplementary in these two country groups.

In all country groups, there is an association between the probability of observing the WME arrangement and the woman being more educated than her partner. Given the emerging gender imbalance in education among the younger cohorts, and given the increasing educational heterogamy among couples with women more educated than their partners, on the basis of our results, we can envisage that in the near future, an increasing number of couples will be characterized by women who earn more than their partners. However it is possible that the contribution of the educational difference among partners on the diffusion of the WME arrangement will be low in countries with lower returns to education (such as Southern European countries).

Other characteristics are specific to selected groups of countries. For example, in Anglo-Saxon, Central-Eastern European, German-speaking and Nordic countries women who are not married to their cohabiting partner are more likely to provide an equal, but not the largest, share of the household income.

In Central-Eastern European, German-speaking and Nordic countries among the richest households, working women are more likely to earn less than their partners. Similarly, women as main earners are associated to poorest incomes in Central-Eastern European countries. Hence, with the exception of Anglo-Saxon and Southern European countries, i.e. the countries witnessing the highest increases in male unemployment rates during the economic crisis, women contribute an equal or the highest share of the household income when they belong to low-income families.

Finally, we documented a significant increase in WME in Southern European and Anglo-Saxon countries in the years of the economic crisis, with Greece and Ireland registering the highest increases. We also find a significant positive association between WME and living in Sweden as well as between equal earners regime and living in France. As of 2010, the effects of the economic crisis may not be entirely revealed. On 
the other hand, in Southern European and Anglo-Saxon countries we do not find any statistically significant association with household income. This lack of significance indicates that we do not find evidence of the hypothesis that women are more likely to contribute household income when they are constrained to do so by a low total household income, nor that women in families with a relatively high household income tend to be out of the labour force, or to contribute only a little share of the total household income. ${ }^{8}$

Research that explicitly looks at women who out-earn their partners has been so far under investigated, in particular for Europe. Our contribution adds to the literature by providing a comprehensive study on women as main earners in Europe. Results presented in this paper identify the correlates of different earning arrangements of couples with working women. Future research will need to study the consequences of the increased economic power of women with respect to their partners' for women, men and their families, as well as society as a whole.

\footnotetext{
${ }^{8}$ Household income is measured in country-specific quintiles, and as such, it is not a measure of the country's reaction to the economic crisis, because if the average income changes, the quintile distribution will not necessarily change accordingly.
} 


\section{REFERENCES}

Aassve, A., Cottini, E. and Vitali, A. (2013) Youth prospects in a time of economic recession. Demographic Research, 29(36), 949-961.

Atkinson, M.P. and Boles, J. (1984) WASP (wives as senior partners). Journal of Marriage and the Family, 46(4), 861-870.

Becker G.S. (1981) A Treatise on the Family. Cambridge: Harvard University Press.

Bernhardt, A., Morris, M. and Handcock, M.S. (1995) Women's gains or men's losses? A closer look at the shrinking gender gap in earnings. American Journal of Sociology, 101(2), 302-328.

Bettio, F., Corsi, M., D'Ippoliti, C., Lyberaki, A., Lodovici, M.S. and Verashchagina, A. (2012) The impact of the economic crisis on the situation of women and men and on gender equality policies. European Commission.

Bianchi, S.M., Casper, L.M. and Peltola, P.K. (1999) A cross-national look at married women's earnings dependency. Gender Issues, 17(3), 3-33.

Bloemen, H.G., and Stancanelli, E.G. (2013) Toyboys or supergirls? An analysis of partners' employment outcomes when she outearns him. Review of Economics of the Household, 1-30. In press.

Blossfeld, H.P. and Drobnic, S. (Eds.). (2001) Careers of Couples in Contemporary Society: From Male Breadwinner to Dual-Breadwinner Families. Oxford: Oxford University Press.

Cho, Y. and Newhouse, D. (2012) How Did the Great Recession Affect Different Types of Workers? Evidence from 17 Middle Income Countries. World Development, 41, 31-50.

Coles, M.G. and Francesconi, M. (2011) On the emergence of toyboys: The timing of marriage with aging and uncertain careers. International Economic Review, 52(3), 825-853.

Crompton, R. (Ed.) (1999) Restructuring gender relations and employment: the decline of the male breadwinner. Oxford: Oxford University Press.

Crompton, S. and Geran, L. (1995) Women as main wage-earners. Perspectives on Labor and Income, 7(4), 26-29.

Daly, M. and Rake, K. (2003) Gender and the welfare state: care, work and welfare in Europe and the USA. Cambridge: Polity Press.

Deutsch, F.M., Roksa, J. and Meeske, C. (2003) How gender counts when couples count their money. Sex Roles, 48(7-8), 291-304.

Drago, R., Black, D. and Wooden, M. (2005) Female breadwinner families. Their existence, persistence and sources. Journal of Sociology, 41(4), 343-362.

England, P. and McClintock, E.A. (2009) The gendered double standard of aging in US marriage markets. Population and Development Review, 35(4), 797-816.

Esping-Andersen, G. (1990) The three worlds of welfare capitalism. Policy Press, Cambridge.

Esping-Andersen, G. (2009) The Incomplete Revolution: Adapting to Women's New Roles. Cambridge: Polity Press.

Ferrera, M. (1996) The "southern model" of welfare in social Europe. Journal of European Social Policy, 6(1), 179-189.

Hakim, C. (2010) Erotic capital. European Sociological Review, 26(5), 499-518.

Harkness, S. (2013) Women, families and the 'great recession' in the UK. In: Ramia, G., Farnsworth, K. and Irving, Z., (Eds.) Social Policy Review 25: Analysis and Debate in Social Policy. Bristol: Policy Press.

Harkness, S. (2010) The contribution of women's employment and earnings to household income inequality: a cross-country analysis (No. 531). LIS Working Paper Series.

Kalmijn, M. (2011) The influence of men's income and employment on marriage and cohabitation: Testing Oppenheimer's theory in Europe. European Journal of Population, 27(3), 269-293. 
Kanji, S. (2010) What keeps mothers in full-time employment?. European Sociological Review, 27(4), 509-525.

Lewis, J. (2001) The decline of the male breadwinner model: implications for work and care. Social Politics: International Studies in Gender, State \& Society, 8(2), 152-169.

Matysiak, A. (2011) Interdependencies between fertility and women's labour supply. European Studies of Population 17. Dordrecht: Springer.

Oppenheimer, V.K. (1994) Women's rising employment and the future of the family in industrial societies. Population and Development Review, 20(2), 293-342.

Parsons, T. (1949) The social structure of the family. In: Anshen, R. (Ed) The Family: Its Function and Destiny. New York: Harper and Brothers, 173-201.

Raley, S.B., Mattingly, M.J. and Bianchi, S.M. (2006) How Dual Are Dual - Income Couples? Documenting Change From 1970 to 2001. Journal of Marriage and Family, 68(1), 11-28.

Rubery, J. (Ed.) (2010). Women and Recession (Routledge Revivals). London: Routledge.

Schwartz, C.R. and Mare, R.D. (2005) Trends in educational assortative marriage from 1940 to 2003. Demography, 42(4), 621-646.

Singh, V., Kalliath, T. and Kalliath, P. (2010) Dual-Income Marital Dyads and Mutually Discrepant Economic Versus Personal Information: An Exploratory Investigation. Psychological Studies, 55(3), 263-269.

Smith, K. (2009) Increased reliance on wives as breadwinners during the first year of the recession. The Carsey Institute at the Scholars' Repository, 88.

Van Bavel, J. (2012) The reversal of gender inequality in education, union formation and fertility in Europe. Vienna Yearbook of Population Research, 10, 127-154.

Van de Kaa, D.J. (1987) Europe's second demographic transition. Population Bulletin, 42(1), 157.

Vincent-Lancrin, S. (2008) The reversal of gender inequalities in higher education: An on-going trend. Higher Education to 2030, Volume 1: Demography, 265-298. Paris: OECD.

Wang, W., Parker, K. and Taylor, P. (2013) Breadwinner Moms. Pew Research Center,1-28.

Winkler, A.E., McBride, T.D. and Andrews, C. (2005) Wives who outearn their husbands: A transitory or persistent phenomenon for couples? Demography, 42(3), 523-535.

Wooden, M. and Hahn, M. (2014) Female breadwinner families. In Wilkins, R. (Ed.) Families, Incomes and Jobs, Volume 9: a statistical report on waves 1 to 11 of the Household, Income and Labour Dynamics in Australia survey.

Zagorsky, J.L. (2003) Husbands' and wives' view of the family finances. The Journal of SocioEconomics, 32(2), 127-146. 
ESRC Centre for Population Change

Building 58, Room 2001

Faculty of Social and Human Sciences

University of Southampton

SO17 1BJ

$\mathrm{T}:+44(0) 2380592579$

E: cpc@soton.ac.uk

www.cpc.ac.uk

To subscribe to the CPC newsletter and keep up-to-date with research activity, news and events, please register online: www.cpc.ac.uk/newsletter

For our latest research updates you can also follow CPC on Twitter, Facebook and Mendeley:

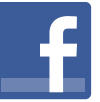

www.facebook.com/CPCpopulation

www.twitter.com/CPCpopulation

www.mendeley.com/groups/3241781/

centre-for-population-change

The ESRC Centre for Population Change (CPC) is a joint initiative between the University of Southampton and a consortium of Scottish universities including St Andrews, Edinburgh, Stirling and Strathclyde, in partnership with the Office for National Statistics and National Records of Scotland.
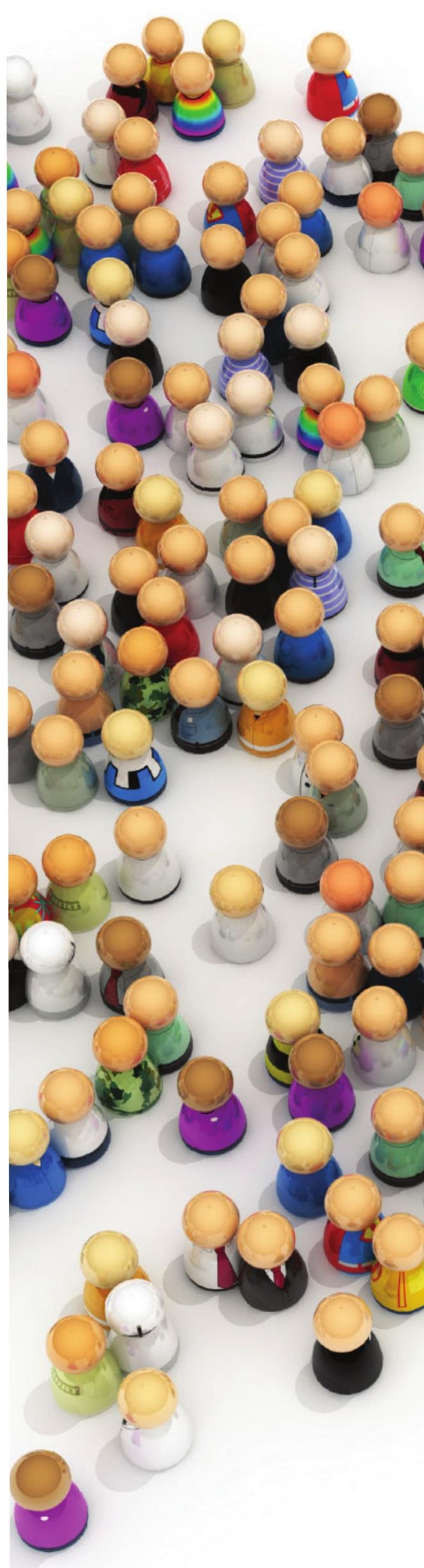